\begin{tabular}{|c|c|c|}
\hline ב & $\begin{array}{l}\text { International Journal of Current Research in } \\
\text { Biosciences and Plant Biology }\end{array}$ & seses= \\
\hline & Volume 7 • Number 6 (June-2020) • ISSN: 2349-8080 (Online) & $0.30 n^{2}$ औs \\
\hline $\begin{array}{l}\text { EXCELLENT } \\
\text { PUBLISHERS }\end{array}$ & Journal homepage: $\underline{w w w . i j c r b p . c o m}$ & \\
\hline
\end{tabular}

\title{
Structuring of the ginger (Zingiber officinale Roscoe.) cultivation system in Côte d'Ivoire and assessment of the morphological variability of rhizomes
}

\author{
Léonie Clémence KOUONON ${ }^{*}$, Bessely Armel Stéphane KOUADIO², Kouamé \\ Guillaume KOFFI ${ }^{1}$, Koudougnon Alice Estère GOBA ${ }^{1}$ and Mongomaké KONE ${ }^{2}$
}

\author{
${ }^{1}$ Université Nangui Abrogoua, UFR Sciences de la Nature, Unité de Phytotechnie et Amélioration Génétique, \\ O2 BP 801 Abidjan 02, Côte d'Ivoire \\ ${ }^{2}$ Université Nangui Abrogoua, UFR Sciences de la Nature, Unité de Physiologie Végétale, \\ 02 BP 801 Abidjan 02, Côte d'Ivoire \\ ${ }^{*}$ Corresponding author; e-mail: ckouonon@yahoo.fr
}

\begin{tabular}{ll}
\hline Article Info & ABSTRACT \\
\hline $\begin{array}{l}\text { Date of Acceptance: } \\
\text { 19 May 2020 }\end{array}$ & $\begin{array}{l}\text { Ginger (Zingiber officinale) is an annual crop, particularly appreciated for its food and } \\
\text { medicinal uses in Côte d'Ivoire. Its uses and by-products depend on the varieties. So, } \\
\text { this study aims to characterize the ginger production system in Côte d'Ivoire and the } \\
\text { mate of Publication: } \\
\text { o6 June 2020 }\end{array}$ \\
$\begin{array}{l}\text { collected where 114 respondents were questioned individually. Qualitative traits (color } \\
\text { of flesh and skin, appearance of ridges on skin, presence or absence of scales on skin } \\
\text { Keywords } \\
\text { and fingers arrangement) of rhizomes were studied. Length and fiber content of the } \\
\text { rhizome were measured. This study reveals that ginger is grown exclusively for rhizome } \\
\text { and primarily for marketing fresh (88\% of producers). Overall producers distinguish } \\
\text { white and yellow flesh. Ginger cultivation is practiced by both women (46\%) and men } \\
\text { Crop }\end{array}$ & $\begin{array}{l}\text { (54\%) from 20 to 75 years. Cultivation takes place on small areas (o.25 to 1 ha). The } \\
\text { most common modalities are yellow flesh (65\%), absence of ridge on skin (78.75\%), }\end{array}$ \\
$\begin{array}{l}\text { Eultivation system } \\
\text { light brown skin (41.25\%), scales on the skin (68.75\%), medium fiber content (61.25\%), } \\
\text { Morphology }\end{array}$ & $\begin{array}{l}\text { short (61.25\%) and packed (68.75\%) fingers. Studies accessions constituted eight } \\
\text { morphological groups. Two of them respectively with 41 and 15 accessions are widely } \\
\text { distributed in six regions and seven regions. }\end{array}$ \\
\hline
\end{tabular}

\section{Introduction}

The quality and availability of arable lands and the diverse climatic conditions supported by agronomic research have favoured the diversification of crop production in Côte d'Ivoire. In addition to cash or industrial crops (cashew, cocoa, coffee, cotton, pineapple, rubber, etc.) and food crops (beans, cassava, maize, millet, plantain, rice, yam, etc.), dozens of other crops are also grown on no less significant scales (Sangaré et al., 2009). Among these crops, Zingiber officinale, commonly known as ginger, is cultivated in forest areas and is becoming increasingly widespread. It is an annual herbaceous crop, of Zingiberaceae family, native to Southeast Asia (Preeti et al., 2008). This highly diverse plant family comprises about 50 genera and more than 1,300 species (Parthasarathy et al., 2012; 
Tamokou et al., 2017), distributed across Asia, Pacific Islands and Africa (Kress et al., 2002; Jatoi et al., 2007). Two species of this family, ginger and curcuma (Curcuma longa L.) are more commonly cultivated in Côte d'Ivoire for rhizomes. Ginger is particularly appreciated for its food and medicinal uses. It is used in medicines to treat gastrointestinal, pulmonary and cancerous (breast, colon, ovary) diseases (Shamsi et al., 2010; Azam et al., 2014). According to Eleazu et al. (2013), its tuberous roots are particularly rich in starch (60\%), proteins, fats (10\%), and oleoresin (4 to $8 \%$ ). The presence in rhizomes of compounds such as shogaol, paradol, gingerol, gingerone and zingerone, gives ginger anti-inflammatory, antioxidant, analgesic, antipyretic, antiemetic, antibacterial and aphrodisiac virtues (Wei and Shibamoto, 2010; Akbarian et al., 2011; Mohaddese, 2019). Essential oils extracted from the rhizome are consisted in geraniol, citral, camphene, and other minor constituents such as zingiberene, curcumene, bisabolene, and linalool (Singh et al., 2011; Begum et al., 2018). While oleoresin and essential oils are commonly used in the food industry, essential oils are also used in perfumery.

In Côte d'Ivoire, the price of fresh rhizomes on urban markets can reach $700 \mathrm{~F} \mathrm{CFA} \mathrm{(about} 1 € / \mathrm{kg}$ ), which is equivalent to the price of dried cocoa beans or twice that of cashew nuts. Consequently, this species became an important source of agricultural income diversification and the raw material for a category of food industries, and the essential oils extracted supply an important export network between Côte d'Ivoire and Europe. Despite the food and therapeutic virtues of ginger, and although it is very much involved in the socio-economic activities of the populations in Côte d'Ivoire, its cultivation is confronted with many factors which limit expansion of the sector. In reality, reported data on national production and the organization of the sector are unreliable, rare and outdated. This reveals clearly the low level of yield, which is estimated to $8 \mathrm{t} / \mathrm{ha}$ while yields can reach $30 \mathrm{t} / \mathrm{ha}$ elsewhere (Okwuowulu, 2005). Other factors such as rudimentary technical itineraries and the absence of improved varieties also justify the low yield. Data on evaluation of the varietal diversity of clones grown in Côte d'Ivoire are not yet available.

Ethnobotanical studies appear to be an excellent tool for understanding the relationships between local populations and a given resource to building up a collection of the heritage of the plant concerned, while characterization studies sustain the preservation of biodiversity. Indeed, the lack of genetic information on a resource can lead to a loss of diversity. In addition, the use of the resource and its by-products depends on the varieties. Therefore, this study aims to characterize the ginger production system in Côte d'Ivoire and to evaluate the variability among local accessions cultivated based on morphological traits of rhizomes for the identification of promising cultivars that either can integrate breeding programs or be validated by farmers for cultivation.

\section{Materials and methods}

\section{Prospecting and collection areas}

Collection of ginger rhizomes was carried out in Côte d'Ivoire, located in West Africa between $4^{\circ} 30^{\prime}-10^{\circ} 30^{\prime}$ North latitude and $2^{\circ} 30^{\prime}-8^{\circ} 30^{\prime}$ West longitude. The prospecting and collection areas comprise seven administrative regions (Fig. 1) located in the Guinean zone (Agnéby-Tiassa, Gôh, Lôh-Djiboua, Nawa) and in the Guineo-Sudanian zone (Gontougo, Moronou, Iffou). Twenty-four localities belonging to these administrative regions were visited. The identification of these localities of culture ginger was made by an approach prospective carried out with the support of decentralized structures of the Ministry of Agriculture and Sustainable Development. It is mainly the national support agency for rural development (ANADER) but also agricultural producer cooperatives.

\section{Prospecting and investigations}

Surveys and collections were achieved during March 2019 (end of the long dry season, just before new plantations were established). Within each agroecological zone, sampling was carried out according to the region- department-village-field stratification. The number of localities prospected per region varies according to the size of the ginger production area visited.

Ethnobotanical data were collected from a random sample of 114 persons. Respondents were questioned individually on the basis of a survey form. Briefly, the collected information was about: 
civil status and school level of producers, local name and origin of ginger, seed supply method, cultural practices, cultivated areas, conservation techniques and the uses of the rhizomes. At the end of the investigation, samples of ginger (accessions) were collected with the producers.

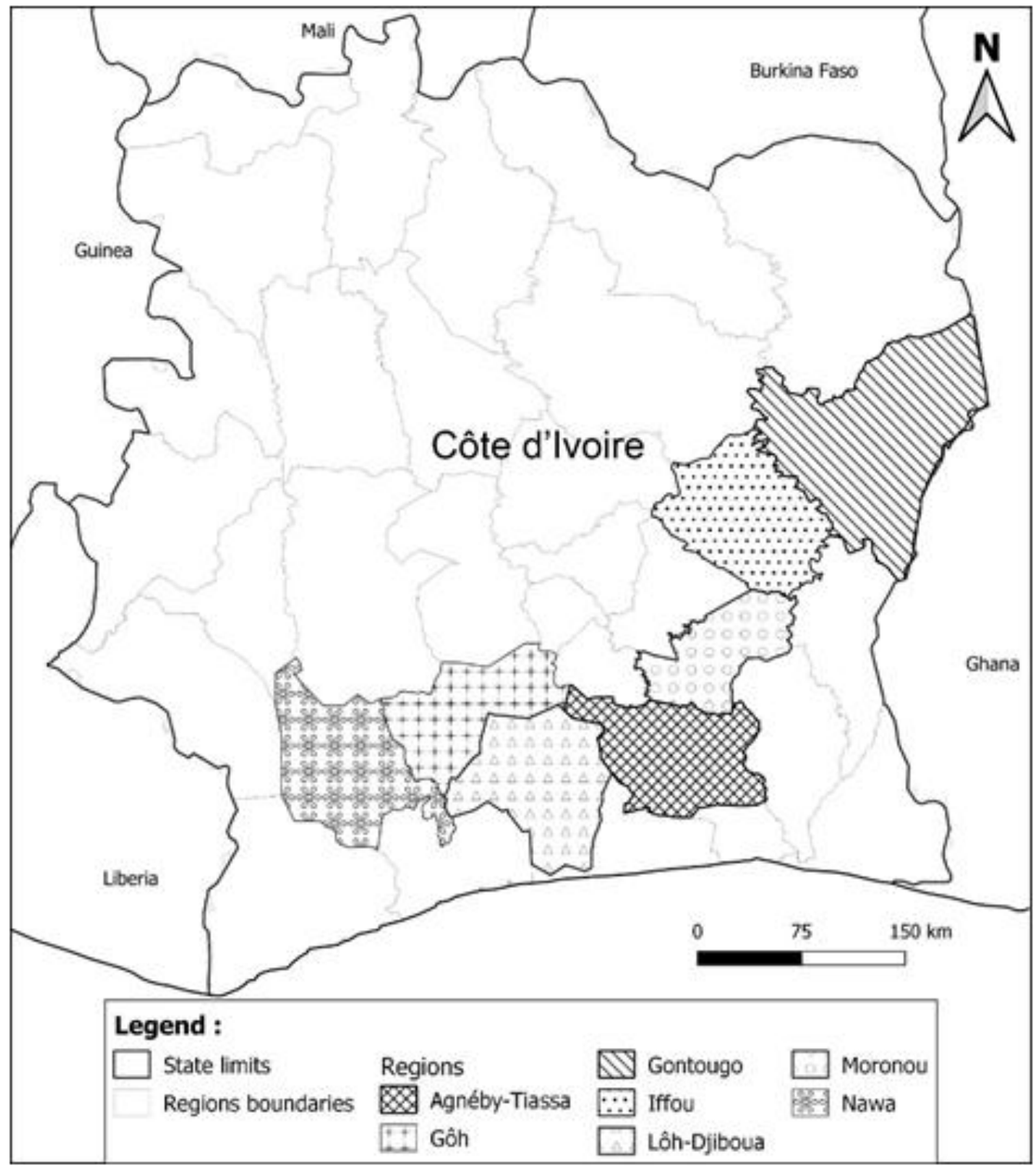

Fig. 1: Different collection zones for ginger accessions.

\section{Morphological characterization}

The ginger accessions collected during prospecting and collection missions were brought back to the Laboratory of Biology and Plant Breeding at the University Nangui Abrogoua. The rhizomes of the different accessions have been thoroughly rinsed with tap water to remove all traces of soil. Residual roots were removed and the surface water of the rhizomes was wiped off with paper towels.
Before the establishment of plots for the conservation of plant genetic resources of ginger and the morphological evaluation of accessions, various qualitative variables were determined on the rhizomes of 80 accessions (Table 1). The color of the flesh was classified as cream, yellow or white. The color of the skin was classified as beige, light brown, and dark brown. The appearance of ridges (protruding or not protruding) on the rhizome skin was noted. Presence or absence of scales on rhizome skin was noted. The length of the 
rhizome was measured using a caliper (Master craft model; $15 \mathrm{~cm}$ long; accuracy $\pm 0.1 \mathrm{~mm}$ ) and classified into two categories: short $(<15 \mathrm{~cm})$ or long $(\geq 15 \mathrm{~cm})$. To determine the fiber content of the rhizome, $100 \mathrm{~g}$ of fresh rhizomes were weighed and finely crushed. The crushed material was washed on a sifter. The residue obtained was dried for $48 \mathrm{~h}$ and then weighed using a precision balance. The arrangement of the fingers is classified into two categories (packed or separate). The parameters studied and the different procedures are coded in Table 2.

Table1. Distribution of accessions based to collection regions.

\begin{tabular}{|c|c|c|}
\hline Regions & Localities & Accessions \\
\hline \multirow{3}{*}{ Agnéby-Tiassa } & Gnassombly & Go01 Go02 \\
\hline & N'Doucy & Go046, Go047 \\
\hline & Tiassalé & Goo9 \\
\hline Goh & Galebre & Goo41 \\
\hline \multirow[t]{2}{*}{ Gontougo } & KounAhouzi & $\begin{array}{l}\text { Goo76, Goo77, Goo78, Goo79, Goo80, Goo81, Goo82, Goo83, Goo84, } \\
\text { Goo85, Goo86, Go087 }\end{array}$ \\
\hline & KounFao & Goo73, Goo74, Goo75 \\
\hline Iffou & Daoukro & Goo62, Goo63, Goo64, Goo65, Goo66, Goo67, Goo68, Goo69 \\
\hline \multirow{4}{*}{ Lôh-Djiboua } & Blé & Goo42, Goo43 \\
\hline & Diankro & Goo45 \\
\hline & Hêrêmankono & Go03, Go07, Goo8, Go010, Go011, Go012, Go013 \\
\hline & Ogoudou & Go015, G0016, Go017, Go018, Go019 \\
\hline \multirow{4}{*}{ Moronou } & Ahorosso & Goo57 \\
\hline & Bongouanou & Goo48, Goo49, Goo50, Goo51, Goo52, Goo53, Goo54, Goo55, Goo56 \\
\hline & Kangadi & Goo58, Goo59, Goo70, Goo72 \\
\hline & M'Batto & Goo6o, Goo61, Goo88 \\
\hline \multirow[t]{2}{*}{ Nawa } & Grand Zatry & $\begin{array}{l}\text { Goo21, Goo22, Goo23, Goo24, Goo25, Goo26, Goo27, Goo28, Goo30, } \\
\text { Goo32, Goo33, Goo34, Goo35, Goo36, Goo37, Goo44 }\end{array}$ \\
\hline & Yabayo & Goo38, Goo39, Goo40 \\
\hline
\end{tabular}

Table 2. Codification of studied parameters and their observed modalities for the description of collected accessions of Zingiber officinale in Côte d'Ivoire.

\begin{tabular}{|c|c|c|c|}
\hline Characters & Character Codes & Terms & Code Terms \\
\hline \multirow[t]{3}{*}{ Flesh color } & \multirow[t]{3}{*}{$\mathrm{CoCh}$} & Beige & CoCh1 \\
\hline & & Yellow & CoCh2 \\
\hline & & White & $\mathrm{CoCh}_{3}$ \\
\hline \multirow[t]{2}{*}{ Ridges appearance } & \multirow[t]{2}{*}{ AsSt } & Not salient & As st1 \\
\hline & & Projecting & As st2 \\
\hline \multirow[t]{3}{*}{ Skin color } & \multirow[t]{3}{*}{ CoEp } & Light brown & CoEp1 \\
\hline & & Dark brown & CoEp2 \\
\hline & & Dark brown & CoEp3 \\
\hline \multirow[t]{2}{*}{ Presence of scales } & \multirow[t]{2}{*}{ PrEc } & No & PrEc1 \\
\hline & & Yes & PrEc2 \\
\hline \multirow[t]{3}{*}{ Fiber content } & \multirow[t]{3}{*}{ TeFi } & Low & Te Fi1 \\
\hline & & Way & Te Fi2 \\
\hline & & Student & Te Fi3 \\
\hline \multirow[t]{2}{*}{ Finger arrangement } & \multirow[t]{2}{*}{ Ag Do } & Packed & AgRa1 \\
\hline & & Separate & AgRa2 \\
\hline \multirow[t]{2}{*}{ Finger length } & \multirow[t]{2}{*}{ LoDo } & Short & LoDo1 \\
\hline & & Long & LoDo2 \\
\hline
\end{tabular}




\section{Data analysis}

Descriptive and exploratory statistics were carried out with the data collected on ginger accessions. Frequencies of qualitative modalities were calculated. Multiple correspondence analysis (MCA) of qualitative morphological traits coded as ordinal data was used to identify all the accessions studied and determine the morphological parameters that contributed to differentiation among accessions.

\section{Results}

\section{Typology of ginger producers}

Ginger cultivation is practiced by both women (46\%) and men (54\%) whose ages range from 20 to 75 years. Three levels of education are used to classify producers in primary school level (14\%), secondary school level (13\%) and a significant proportion of no schooled (69\%). In AgnébyTiassa, Lôh-Djiboua and Nawa regions, cultivation is mainly practiced by non-natives (respectively $100 \%, 79 \%$ and $67 \%$ ) against $0 \%, 21 \%$ and $33 \%$ of non-natives. In return, the cultivation is mainly practiced by the natives in Moronou (94\%) and Gontougo (50\%) regions.

\section{Cultivated varieties}

Overall producers distinguish two types of ginger according to the color of the flesh: white and yellow flesh which are cultivated in Agnéby-Tiassa, Lôh-Djiboua, Moronou and Nawa. The white flesh type is the preponderant one in these regions. In Gontougo, the yellow flesh type is the most cultivated. In this region, out of 17 producers, only one had white flesh type.

\section{Cultural practices}

\section{Method of obtaining plant material}

The plant material used by the producers comes from their own villages or surrounding villages. The most common method of rhizomes procurement is the purchase (57\%), followed by donations (32\%, this method of obtaining plant material involves donations, inheritance and exchanges by parents, friends or acquaintances) and selection (11\%) from the producers of their own production.

\section{Harvested areas}

In all regions surveyed, cultivation takes place in fields on small areas. It can be seen that the majority of producers (96\%) produce on areas between 0.25 and 1 ha. Only $4 \%$ of producers have areas larger than one (01) ha. A farm business, Agriland, in Agnéby-Tiassa occupies 84 ha.

\section{Plot preparation and sowing}

In all regions, the first operation consists of clearing the plots and then burning the residues. But in the Agnéby-Tiassa and Lôh-Djiboua regions, these residues are burned at the foot of the trees. Direct seeding without ploughing or ridging is the most common method used by producers (79\%) and is done in staggered rows in Gontougo.

Moreover, the making of ridges and mounds is not very widespread and is only practiced in Moronou and Iffou. In these regions, a very high proportion of producers (100\%) use both practices. All the 114 producers claim that the planting of the rhizomes takes place between March and June, i.e. when the rains start. Ginger can be cultivated pure or in combination. The association with corn is practiced in the regions of Agnéby-Tiassa, Lôh-Djiboua and Gontougo. Cultivation on mounds or ridges in association with maize, taro and manioc is practised exclusively in the Moronou region. The farm business, Agriland, in Agnéby-Tiassa uses the shade plant Glyricidia sepium.

\section{Plot maintenance and crop monitoring}

Plot maintenance consists mainly of manual weeding. All growers in seven of the surveyed regions maintain that the ginger plots are maintained on a continuous basis throughout the development period. Weeding starts from the fourth week after emergence. Two methods are known, hand pulling and weeding. Growers practice one or the other without any particular preference. Two to three weedings are required during the crop cycle depending on the type of weed and the degree of weed control. No farmer uses any phytosanitary product for weeding. 
Table 3: Proportion of modalities of ginger accessions in seven regions of Côte d'Ivoire.

\begin{tabular}{|c|c|c|c|c|c|c|c|c|c|}
\hline \multirow{2}{*}{$\begin{array}{l}\text { Parameter } \\
\text { codes }\end{array}$} & \multirow{2}{*}{$\begin{array}{l}\text { Modality } \\
\text { codes }\end{array}$} & \multirow{2}{*}{$\begin{array}{l}\text { Total } \\
\text { (\%) }\end{array}$} & \multicolumn{7}{|l|}{ Regions (\%) } \\
\hline & & & Agnéby-Tiassa & Loh-Djiboua & Nawa & Moronou & Iffou & Gontougo & Goh \\
\hline \multirow[t]{3}{*}{$\mathrm{CoCh}$} & CoCh-1 & 11.25 & 40 & $13 \cdot 33$ & 10.53 & 5.88 & 12.50 & 6.67 & $\mathrm{O}$ \\
\hline & CoCh-2 & 65 & 0 & 33.33 & 57.89 & 94.12 & 75.00 & 93.33 & o \\
\hline & $\mathrm{CoCh}-3$ & 23.75 & 60 & 53.33 & 31.58 & 0.00 & 12.50 & 0.00 & 100 \\
\hline \multirow[t]{2}{*}{ AsSt } & AsSt-1 & 78.75 & 80 & 66.67 & 57.89 & 82.35 & 100.00 & 100.00 & 100 \\
\hline & AsSt-2 & 21.25 & 20 & 33.33 & 42.11 & 17.65 & 0.00 & 0.00 & $\mathrm{O}$ \\
\hline \multirow[t]{3}{*}{ CoEp } & CoEp-1 & 36.25 & 60 & 26.67 & 26.32 & 58.82 & 37.50 & 26.67 & $\mathrm{O}$ \\
\hline & CoEp-2 & 41.25 & 20 & 46.67 & 57.89 & 35.29 & 0.00 & 53.33 & $\mathrm{O}$ \\
\hline & CoEp-3 & 22.5 & 20 & 26.67 & $15 \cdot 79$ & 5.88 & 62.50 & 20.00 & 100 \\
\hline \multirow[t]{2}{*}{ PrEc } & PrEc-1 & 31.25 & 20 & $13 \cdot 33$ & 31.58 & 47.06 & 37.50 & 33.33 & $\mathrm{O}$ \\
\hline & PrEc-2 & 68.75 & 80 & 86.67 & 68.42 & 52.94 & 62.50 & 66.67 & 100 \\
\hline \multirow[t]{3}{*}{$\mathrm{TeFi}$} & TeFi-1 & 3.75 & 0 & 13.33 & 5.26 & 0.00 & 0.00 & 0.00 & 0 \\
\hline & TeFi-2 & 61.25 & 80 & 73.33 & 57.89 & 82.35 & 100.00 & 0.00 & 100 \\
\hline & TeFi-3 & 35 & 20 & $13 \cdot 33$ & 36.84 & 17.65 & 0.00 & 100.00 & $\mathrm{O}$ \\
\hline \multirow[t]{2}{*}{ AgDo } & AgDo-1 & 68.75 & 80 & 80.00 & 63.16 & 82.35 & 50.00 & 53.33 & 100 \\
\hline & AgDo-2 & 31.25 & 20 & 20.00 & 36.84 & 17.65 & 50.00 & 46.67 & $\mathrm{O}$ \\
\hline \multirow[t]{2}{*}{ LoDo } & LoDo-1 & 61.25 & 80 & 60.00 & 84.21 & 41.18 & 25.00 & 66.67 & 100 \\
\hline & LoDo-2 & 38.75 & 20 & 40.00 & 15.79 & 58.82 & 75.00 & 33.33 & O \\
\hline
\end{tabular}


All growers cultivate ginger without the use of organic or mineral fertilizers. One farm business use green, organic and mineral fertilizers and motorized machinery for soil preparation: spraying, ploughing and ridging.

\section{Harvest and conservation}

All growers associate rhizome maturation with yellowing of leaves and stems. They attribute an age of 6 to 9 months to a mature plant. However, in all regions, harvesting is based on market demand. The conservation of rhizomes in the soil is the most common conservation practice. However, once harvested, rhizomes can be stored for short periods of two months. In this case, storage can be done in the field where the rhizomes are covered with straw or dried leaves to protect the rhizomes from the effect of the sun. In other cases, the ginger is bagged and stored in shady places.

\section{Uses and becoming of harvested products}

Ginger is considered aS cash crop by farmers. In all production regions, ginger is grown primarily for marketing fresh (88\% of producers) or dried (12\% of producers) on local markets, in Abidjan or in the sub-region (Burkina Faso, Ghana, Mali and Senegal). According to the producers (100\%), ginger is grown exclusively for its rhizome. It is used in several ways for food purposes: dried and ground, it is used as a spice to flavor sauces, tea, herbal teas and coffee. When fresh, it is peeled and ground to extract the juice which is used to make soft drinks. Rhizomes are also dried and sold as cough drops or appetizers. In Tiassalé (AgnebyTiassa region), a small production unit extracts essential oils from the white ginger rhizome.

In medicinal use, ginger is used as a suppository, enema or orally by producers for the treatment of remedies for several diseases including coughs, colds, constipation, haemorrhoids, etc.

\section{Morphological variability among the collected accessions}

Eighty accessions were harvested through seven regions. Three parameters (flesh color, skin color and fiber content) out of the seven studied, revealed three distinct modalities; the remaining four parameters revealed two modalities each (Table 3). On overall accessions, the most common modalities are yellow flesh (65\%), absence of ridge on the skin (78.75\%), light brown skin (41.25\%), presence of scales on the skin (68.75\%), medium fiber content (61.25\%), short fingers (61.25\%) and packed arrangement (68.75\%). According to the region, the most common modalities differ; for example, the yellow flesh is absent in AgnébyTiassa, infrequent in Lôh-Djiboua, whereas it is in the majority in Nawa (57.89\%), Gontougo (93.33\%) and Moronou (94.12\%). Low-fiber accessions were collected in Lôh-Djiboua (13.33\%) and Nawa (5.26\%). In Gontougo, almost accessions are very fibrous, short fingers (66.67\%) and compact (53.33\%).

\section{Accessions structuring into morphological groups}

The first two factor axes of the MCA express $41.36 \%$ and $14.36 \%$ of the morphological variability, respectively (Table 4, Fig. 2 and Fig. 3). These two axes account for $55.73 \%$ of the total inertia. For each of the parameters studied, at least one modality has a significant contribution to the formation of one of the first two axes (Table 2). The modalities which contributed to the formation of axis 1 are, in order of importance: absence of ridge on the skin (21.57\%), brown skin (14.97\%), absence of scales on skin (10.10\%) separate fingers (9.75\%). The modalities which contributed to the formation of axis 2 are, in order of importance: cream flesh (30.05\%), high fiber content (17.40\%), long (16.68\%) and short fingers (8.50\%), absence of scales on the skin (8.97\%).

Table 4. Eigen values, percentage of discrimination in axes 1 and 2 and correlation coefficients between variables and axes.

\begin{tabular}{lll}
\hline & Axis 1 & Axis 2 \\
\hline Eigen values & 0.24 & 0.20 \\
\hline Adjusted inertia & 0.01 & 0.00 \\
Adjusted inertia (\%) & 41.37 & 14.73 \\
Cumulated percentage & 41.37 & 55.74 \\
\hline CoCh-1 & 3.21 & $\mathbf{3 0 . 0 5}$ \\
AsSt-2 & $\mathbf{2 1 . 5 7}$ & 0.00 \\
CoEp-3 & $\mathbf{1 4 . 9 7}$ & 0.09 \\
PrEc-1 & $\mathbf{1 0 . 1 0}$ & $\mathbf{8 . 9 7}$ \\
TeFi-3 & 3.70 & $\mathbf{1 7 . 4 0}$ \\
AgDo-2 & $\mathbf{9 . 7 5}$ & 0.03 \\
LoDo-1 & 0.04 & $\mathbf{8 . 5 0}$ \\
LoDo-2 & 0.08 & $\mathbf{1 6 . 6 9}$ \\
\hline
\end{tabular}




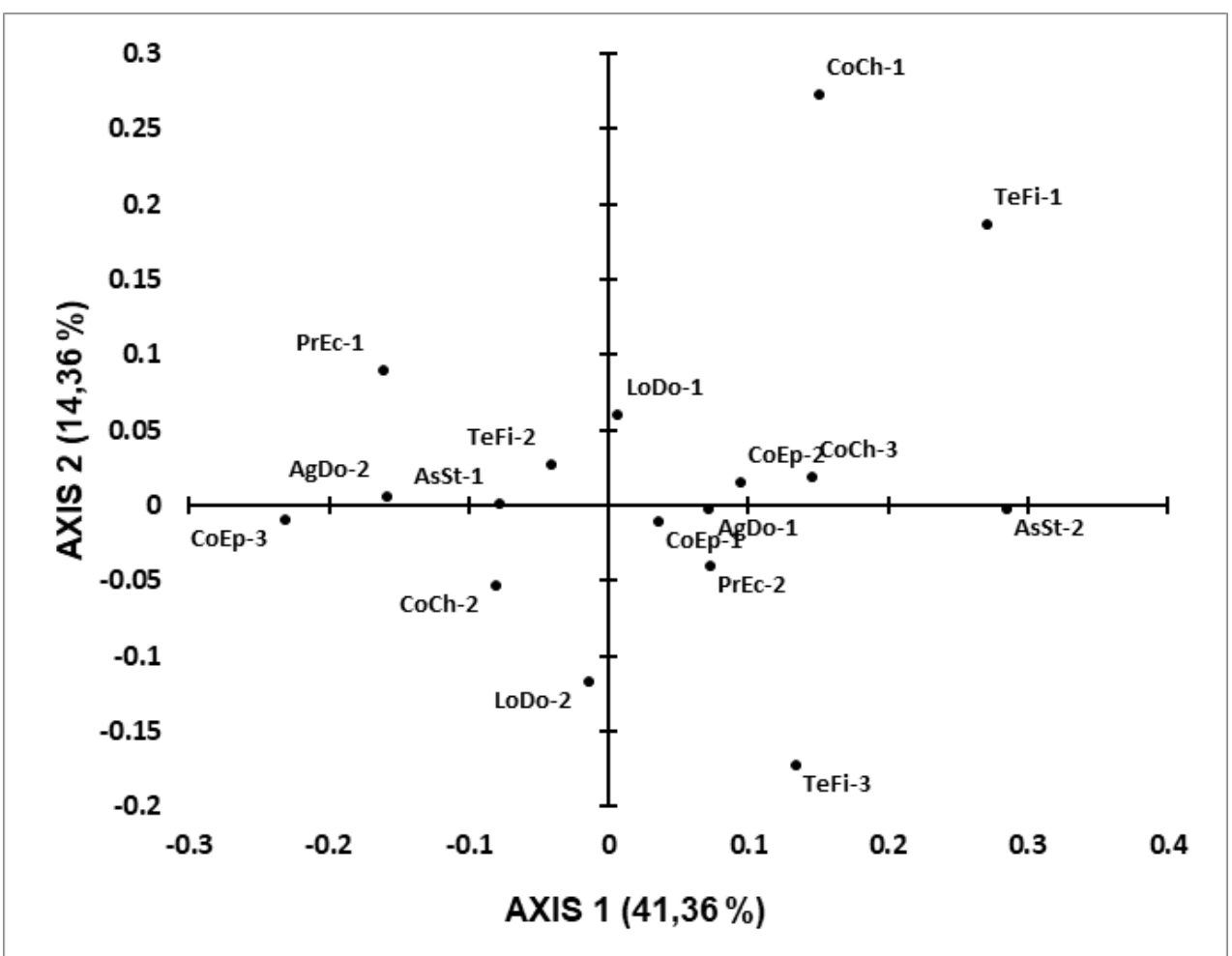

Fig. 2: Projections of modalities in the discriminant canonical plane formed by canonical components 1 and 2.

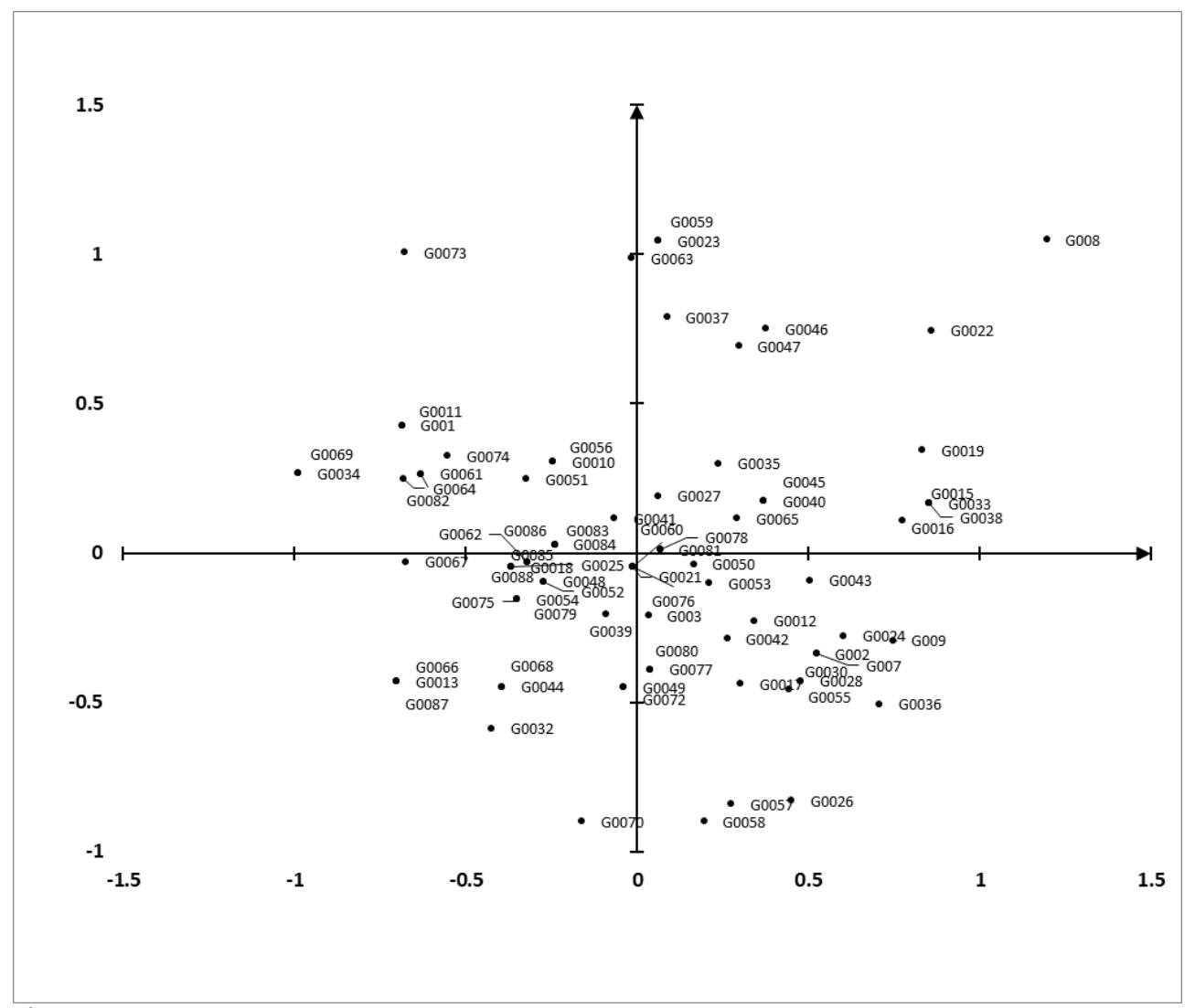

Fig. 3: Multiple Correspondence Analysis (MCA) of Côte d'Ivoire ginger accessions based on qualitative traits. 
The 80 ginger accessions can be split into eight groups. In the center of the factorial plane, the accessions (group 1, 41 accessions: Goo1, Goo3, Goo10, Go11, Goo18, Goo21, Goo25, Goo27, Goo34, Goo35, Go039, Goo40, Goo41, Goo43, Goo45, Goo48, Go050, Goo51, Goo52, Goo53, Goo54, Goo56, Goo6o, Goo61, Goo62, Goo64, Goo65, Goo67, Goo69, Goo74, Goo75, Goo76, Goo78, Goo79, Goo81, Goo82, Goo83, Goo84, Goo85, Goo86 and Goo88) have beige/light brown skin, white flesh, short fingers, medium/high fiber content and scales on skin. In the extreme negative part of axis 2, four accessions (group 2: Go026, Go057, Go058 and Goo70) are characterized by long fingers, high fiber content, yellow flesh and scales on the skin. In the negative part of axes 1 and 2, six accessions (group 3 Goo13, Goo32, Goo44, Goo66, Goo68 and Goo87) are characterized by yellow flesh, non-protruding ridges and long fingers. In the positive part of axis 1 and negative part of axis 2, 15 accessions (group 4: Go02, Goo7, Goo9, Go12, Goo17, Goo24, Goo28, Goo3o, Goo36, Goo42, Goo49, Goo55, Go072, Goo77 and Goo80), are characterized by a yellow/white flesh, medium fiber content, absence of scales on the skin, short fingers and nonprotruding ridge. An isolated accession (Go73, Group 5) has cream flesh, non-protruding ridges, light brown skin, medium fiber content, separate and short fingers. Six accessions (group 6: Goo23, Go037, Go046, Go047, Goo59 and Goo63) of cream/white flesh and beige/light brown skin, low/medium fiber content, non-protruding ridges and short fingers form one group, at the positive end of axis 2. Two accessions (Goo8 and G022) of cream flesh, with protruding ridges, scales on skin, short and packed finger constitute group 7. Group 8 consists of five accessions (Goo15, Goo16, Goo19, Goo33 and Go038) characterized by cream/white flesh, prominent ridges, beige/light brown skin, scales on skin, medium fiber content and separate fingers.

\section{Geographical distribution of morphological groups}

Two of the eight morphological groups are widely distributed in six regions for group 1 (with 41 accessions) and seven regions for group 4 (with 15 accessions). Groups 3 (with six accessions) and 6 (with six accessions) are cultivated in four regions: Lôh-Djiboua, Nawa, Iffou and Gontougo for group
3, and Agnéby-Tiassa, Nawa, Moronou and Iffou for group 6. Group 5 consists of a single accession from Gontougo. Three groups are found in two regions: Nawa and Moronou for group 2 (with four accessions), Lôh-Djiboua and Nawa for groups 7 (with two accessions) and group 8 (with five accessions).

\section{Discussion}

Morphological characterization is an important step in the description and classification of crop germplasm (Manzano et al., 2001; Yobi et al., 2002). Indeed, any improvement program necessarily relies on the characterization of cultivated accessions. Qualitative traits, in morphological characterization, are important for the description of the plants. These are the units of diversity from which farmers and peasants, the main managers of varietal diversity, classify the different local varieties (Sawadogo et al., 2010). The use of qualitative traits involves descriptive codes that show more or less discontinuous genetic variation (Mitu, 2019). The present study aims at the characterization based on qualitative agromorphological descriptors of 80 accessions of a high socio-cultural and economic value plant, ginger, produced in Côte d'Ivoire.

\section{Typology of producers}

In the surveyed regions, ginger is grown mainly by men (54\%) on small areas (96\%) of between 0.25 and 1 ha. This typology of producers is consistent with that of ginger producers in Burkina Faso as described by Nandkangre et al. (2015). Indeed, ginger cultivation is dominated by men and is practiced on small plots of no more than 1 ha. Most of the producers in Côte d'Ivoire (57\%) buy rhizomes with other producers or on local markets to grow the next crop.

The ethnocultural landscape of Côte d'Ivoire is clearly structured. Culture is mainly practised by non-natives (Malinké and Sénoufo) and nonnatives (Mali and Burkina Faso) in the administrative regions of southern and western Côte d'Ivoire (Agnéby-Tiassa, Lôh-Djiboua and Nawa). On the other hand, it is mainly the work of indigenous people in the Moronou (Agni) and Gontougo (Agni and Abron) regions in the east of Côte d'Ivoire. Western Côte d'Ivoire has indeed 
experienced a history of strong rural migration from several neighbouring countries and other parts of Côte d'Ivoire where land pressures and climate change are affecting land availability. In the recent past, this area was characterized by dense evergreen forests and numerous rivers. Moreover, the agricultural sector still occupies $80 \%$ of the active population in this region today.

\section{Morphological variability}

Although the mode of propagation of ginger is the vegetative type, there is great variability within the species (Nayak et al., 2005). Thus, the present study has revealed significant differences on qualitative traits such as the presence of ridges, scales on skin, fiber content, fingers arrangement, fingers size and the colour of the flesh which is not only white or yellow according to most of producers interviewed, but with intermediate modality, beige. These observations are like those obtained by Nandkangre et al. (2015) on morphological distinctive traits of cultivars.

\section{Cultural practices and production}

This study identified 24 ginger-growing localities in Côte d'Ivoire within 7 administrative regions. The principal production areas were Hermankono and KounFao, where a large number of producers are concentrated. The study showed inexistence of statistical data in Côte d'Ivoire on ginger cultivation kept by the national rural development support structure because ginger is not yet included among the interesting speculations. It is not possible to have exact data on ginger production and the national area under ginger cultivation. However, Côte d'Ivoire remains a small producer of ginger because estimates of the harvest, which is spread throughout the year at the request of the market, are very low: 2 to 10 tonnes per hectare. The general observation is that in all the regions surveyed, the areas cultivated for ginger production are themselves small, with producers in most cases (96\%) devoting only a quarter to one hectare of land to ginger production. Only $4 \%$ of the producers surveyed occupy areas larger than one hectare (never more than 2 ha). Within this group, Agriland, an essential oil extraction farm, uses 84 hectares of land for an average yield of 15 tonnes per hectare. This is the only farm that complies with specifications based on a semi-modern technical itinerary. For the others, cultivation techniques remain similar from one region to another and are characterized by traditional practices: absence of inputs (refusals) and improved varieties. The cultivation of ginger follows the cycle of others food crops, which are integrated into the land use programme in temporal or spatial cultural associations with ginger. The cultivation of ginger is dependent for irrigation on rainfall alone, which has become very uncertain.

\section{Uses and purpose of production}

In Côte d'Ivoire, the main use of ginger is the manufacture of beverages from extracts of the peeled rhizome. White ginger produces a highly spicy drink, but its colour and presentation are modified by the addition of industrial colourings giving it a sparkle. Yellow ginger, on the other hand, which seems to be in greater demand on the markets, is used to make a less spicy drink with a nice colouring. In addition, the dried and ground rhizome is highly appreciated in coffee and tea. Okonta et al. (2008) state that it is used as a spice or condiment and it is also used as a phytotherapeutic agent. Ginger is used in the manufacture of beverages such as beer, liquor and in the preservation of certain products (Nair, 2019). In local markets, the rhizomes are cut into thin slices, dried and sprinkled with sugar and sold as snacks. Ginger is used for the treatment of certain illnesses such as colds, constipation, nausea, haemorrhoids, angina, stomach aches, coughs, etc. (Nair, 2019). It is also used in the Chinese pharmacopoeia according to Vendruscolo et al. (2006) for the treatment of many diseases.

Ginger cultivated in Africa is known to be rich in essential oils compared to ginger from Asia in particular (Toure and Xiaoming, 2007; Onyenekwe and Hashimoto, 1999). According to Ajayi et al. (2013) white ginger has a richer essential oil composition than yellow ginger but Prakash (2016) showed that some yellow-fleshed varieties contain much higher quantities of essential oils than whitefleshed varieties. In case, the essential oils of ginger contain a mixture of chemical compounds that contribute to the fragrance but also to its medicinal properties. 


\section{Accessions structuring into morphological groups}

Multiple Component Analysis (MCA) was used to determine the parameters that best expressed variability within the collection and to define homogeneous groups of accessions. This analysis revealed significant heterogeneity within the ginger accessions collected. This phenotypic heterogeneity is reflected in the scattering of the points cloud. Phenotypic heterogeneity can be of genetic origin, but can also be influenced by environmental factors (Adoukonou-Sagbadja et al., 2007).

The variation observed in the canonical plane of the first two axes expresses $55.72 \%$ of the total variation. Based on the contributions of the qualitative parameters (at the $7 \%$ threshold) to the formation of these retained axes, only eight of the 17 observed modalities describe the morphological variation within the collection. These are: cream flesh (CoCh-1), prominent ridges on skin (AsSt-2), dark brown skin (CoEp-3), absence of scales on the skin (PrEc-1), high fiber content (TeFi-3), separate fingers (AgDo-2), short fingers (LoDo-1) and long fingers (LoDo-2).

The MCA has made it possible to establish reconciling links among accessions on the one hand and convergences among variables on the other. Eight morphological groups were revealed: Group 1 contains ginger rhizomes with beige/light brown skin, white flesh, short fingers with medium/high fiber content and scales on the skin. The second group is characterized by yellow flesh, long fingers, high fiber content and scales on the skin. The third group is characterized by yellow flesh, non-protruding ridges and long fingers. The fourth group is characterized by yellow / white flesh, medium fiber content, absence of scales on the skin, short fingers and non- protruding ridges.

Group 5 contains a unique accession of cream flesh, non-protruding ridges, dark brown skin, medium fiber content, separate and short fingers. Group 6 contains individuals with cream/white flesh and beige/light brown skin, low/medium fiber content, non-protruding ridges and short fingers. Group 7 individuals have a cream flesh, prominent ridges on the skin, scales on the skin, short and packed fingers. The last group of individuals (group 8) consists of individuals with white/cream flesh, prominent ridges, beige/light brown skin, scales on the skin, medium fiber content and separate fingers.

Finally, most of the accessions in our study are yellow flesh (65\%) with fine ridges (78.75\%), light brown skin (41.25\%) with scales (68.75\%), medium fiber content (61.25\%) with packed fingers (68.75\%), and short fingers (68.75\%). Fiber content is closely related to the evolution of the cultivar. Fiber content, often cited as an important factor in defining ginger quality, varied mainly between 3 to $7 \%$. The quantity of fiber present in the rhizomes influences the quality of the product, it would significantly impact the yield, it reflects the useful quantity of ginger, but also the quality of the variety. The fiber content of the different accessions would be an important factor for selection in breeding programs (Akshitha et al., 2018).

\section{Geographical distribution of morphological groups}

Eight morphological groups of ginger were defined. Groups 1 and 4 can be found in all ginger growing regions surveyed. These two groups of accessions would constitute the most widespread forms of ginger in Côte d'Ivoire. They are shortfingers with medium/high fiber content, characteristic of unimproved varieties. Both groups contain both white and yellow flesh. The two groups with yellow flesh and long fingers are groups 2 (Nawa and Moronou) and 3 (LôhDjiboua, Nawa, Iffou and Gontougo). Nawa is the region with the highest concentration of morphological groups (seven), followed by LôhDjiboua. Gontougo, Iffou and Moronou concentrate four morphological groups each one. In Agnéby-Tiassa, where an unit of essential oils extraction is installed, only white or cream flesh, belonging to morphological groups 1,4 and 6 are cultivated because rhizomes with yellow flesh would contain less essential oils according to the extraction essential oils unit. In Gontougo, the cultivated forms are essentially yellow flesh, belonging to groups 1, 3 and 4 . In this region, the production is intended for juice extraction, this use would be better suited to the flesh of rhizomes that do not blacken in contact with the air, otherwise food colouring would have to be added. 


\section{Conclusion}

This study provides knowledge on the morphological variability of ginger in the production regions of Côte d'Ivoire. Although farmers underestimate this high variability, they maintain a significant biological diversity through exchanges. Some traits are intimately associated with regions because they depend on the use of the production. Thus, market demand influences the choice of forms cultivated in the production regions. The qualitative study identified eight morphological groups of ginger based on rhizome traits. Most of the morphological groups have short fingers (groups 1, 4, 5, 6, 7 and 8), which are characteristic of traditional varieties. Only groups 2 and 3 with yellow flesh have long fingers. Given the economic interest in ginger cultivation in Côte d'Ivoire, an improvement of the forms cultivated by selection or introduction of improved varieties would be beneficial to farmers and then ascent industry for the exploitation of this resource.

\section{Conflict of interest statement}

Authors declare that they have no conflict of interest.

\section{References}

Adoukonou-Sagbadja, H., Wagner, C., Dansi, A., Ahlemeyer, J., Dainou, O., Akpagana, K., Ordon, F., Friedt, W., 2007. Genetic diversity and population differentiation of fonio millet (Digitaria spp.) land races from different agroecological zones of West Africa. Theor. Appl. Genet. 115(7), 917-931.

Ajayi, O.B., Akomolafe, S.F., Akinyemi F.T., 2013. Food value of two varieties of ginger (Zingiber officinale) commonly consumed in Nigeria. ISRN Nutr. 2013, 359727.

Akbarian, A., Abolghasem, G., Ahmadi, S., Hossein, M., 2011. Effects of ginger root (Zingiber officinale) on egg yolk cholesterol, antioxidant status and performance of laying hens. J. Appl. Anim. Sci. 39, 19-21.

Akshitha, H. J., Prasath, D., Umesha, K., 2018. Association studies for yield and quality traits in ginger (Zingiber officinaleRosc.). Int. J. Innov. Hort. 7(2), 143-145.

Azam, R., Jabeen, A., Alam, T., Mushtaq, S., Mohmad, S. H., 2014. Zanjabil (Zingiber officinalis): A Review. J. Pharm. Innov. Sci. 3(4), 278-282.

Begum, T., Pandey, S.K., Borah, A., Paw, M., Lal, M., 2018. Essential oil composition of different accessions of ginger collected from northeast region of India, J. Essent. Oil Bear. Pl. 21(6), $1475-1486$.

Eleazu, C.O., Amadi, C.O., Iwo, G., Nwosu, P., Ironua, C.F., 2013. Chemical composition and free radical scavenging activities of 10 Elite accessions of ginger (Zingiber officinale Roscoe). J. Clin. Toxicol. 3, 155.

Jatoi, S.A., Kikuchi, A., Watanabe, K.N., 2007. Genetic diversity, cytology, and systematic and phylogenetic studies in Zingiberaceae. Genes Genomes Genomics 1, 56-62.

Kress, W.J., Prince, L. M., Williams, K. J., 2002. The phylogeny and a new classification of the gingers (Zingiberaceae): evidence from molecular data. Amer. J. Bot. 89, 1682-1696.

Manzano, A., Nodals, R., Mayor, F., Gutierrez, R., Alfonso, C., 2001. Morphological and isoenzyme variability of taro (Colocasia esculenta L. Schott) germplasm in Cuba. Plant Genet. Resour. Newsl. 126(6), 31-40.

Mitu, De, 2019. Use of Descriptor codes in agromorphological characterization: qualitative assessment of 20 land races of rice (Oryza sativa L.) from West Bengal. Int. J. Adv. Life Sci. Res. 2(2) 21-26.

Mohaddese, M., 2019. Zingiber officinale Rosc. essential oil, a review on its composition and bioactivity. Clin. Phytosci. 5(1), 6.

Nair, K.P., 2019. Turmeric (Curcuma longa L.) and Ginger (Zingiber officinale Rosc.) - World's Invaluable Medicinal Spices. The Agronomy and Economy of Turmeric and Ginger. Springer Nature Switzerland AG, Switzerland. 568p.

Nandkangre, H., Ouedraogo, M., Sawadogo, M., 2015. Caractérisation du système de production $\mathrm{du}$ gingembre (Zingiber officinale Rosc.) au Burkina Faso: Potentialités, contraintes et perspectives. Int. J. Biol. Chem. Sci. 9(2), 861873.

Nayak, S., Naik, P. K., Qcharya, L., Mukherjee, A. K., Panda, P. C., Das, P., 2005. Assessment of genetic diversity among 16 promising cultivars of ginger using cytological and molecular markers. Z. Naturforsch. 6oc, 485-492.

Okonta, J. M., Uboh, M., Obonga, W. O., 2008. Herb-drug interaction: A case study of effect of ginger on the pharmacokinetic of 
metronidazole in rabbit. Indian. J. Pharm. Sci. 70, 230-242.

Okwuowulu, P. A., 2005. Ginger in Africa and the Pacific Ocean Islands. InMedicinal and aromatic plants-Industrial profiles: Ginger, the genus Zingiber, (Ed.: Ravindran, P.N., Babu, K.N.). CRC Press: Washington DC. pp. 279304.

Onyenekwe, P. C., Hashimoto, S., 1999. The composition of the essential oil of dried Nigerian ginger (Zingiber officinale Roscoe). Eur. Food Res. Technol. 209, 407-410.

Parthasarathy, V. A., Srinivasan, V., Nair,R. R., John, Z. T., Kumar, A., Prasath, D., 2012. Ginger: Botany and Horticulture. Indian Institute of Spices Research Indian Council of Agricultural Research. Kerala, India. p.388.

Prakash, S.A.B., 2016. Nepal ginger profile 2016: research report: an assessment of commercial ginger cultivated in Nepal. Samarth, Kathamndu, Nepal. p.88.

Preeti, C., Dnyaneshwar, W., Kalpana, J., Bhushan, P., 2008. Development of SCAR (sequencecharacterized amplified region) markers as a complementary tool for identification of ginger (Zingiber officinale Roscoe) from crude drugs and multicomponent formulations. Biotech. Appl. Biochem. 50, 61-69.

Sangaré, A., Koffi, E., Akamou, F., 2009. Etat des ressources phylogénétiques pour l'alimentation et l'agriculture. Second rapport national. Ministère de l'agriculture, Abidjan, Côte d'Ivoire. p.65.

Sawadogo, M., Ouedraogo, J., Tignegré, J. B., Drabo, I., Balma, D., 2010. Caractérisation agromorphologique et moléculaire de cultivars locaux de niébé (Vigna unguiculata) du
Burkina Faso. Cameroon J. Exp. Biol. 6(1), 3140.

Shamsi, S., Tajuddin, T., Afaq, S. H., 2010. Spice and medicine: Zingiber officinale, Int. J. Appl. Biol. Pharma. 1(3), 968-973.

Singh, G., Kapoor, I.P.S., Singh, P., Heluani, C.S., Soong, Y., Rong, J.L., Yu, T.Y., Jun, Y.L., Chung, Y.C., 2011. A new phenylalkanoid from the rhizomes of Zingiber officinale. Nat. Prod. Res. 26, 1318-1322.

Tamokou, J.D.D., Mbaveng, A.T., Kuete, V., 2017. Chapter 8 - Antimicrobial Activities of African Medicinal Spices and Vegetables. In: Medicinal Spices and Vegetables from Africa Therapeutic Potential Against Metabolic, Inflammatory, Infectious and Systemic Diseases Academic Press, Cambridge, Massachusetts, ÉtatsUnis.Last accessed on Friday, 6 March, 2020.

Toure, A., Xiaoming, Z., 2007. Gas chromatographic analysis of volatile components of Guinean and Chinese ginger oils (Zingiber officinale) extracted by steam distillation. J. Agron. 6(2), 350-355.

Vendruscolo, A., Takaki, I., Bersani-Amado, L.E., Dantas, J.A., Bersani-Amado; C.A., Cuman; R.K.N., 2006. Anti-inflammatory and antinociceptive activities of Zingiber officinale Roscoe essential oil in experimental animal models. Indian J. Pharm.38, 58-59.

Wei, A., Shibamoto, T., 2010. Antioxidant/ lipoxygenase inhibitory activities and chemical compositions of selected essential oils. J. Agric. Food Chem. 58, 7218-7225.

Yobi, A., Henchi, B., Neffati, M., Jendoubi, R., 2002. Système de reproduction et variabilité morphophenologique chez Allium roseum. Plant Genet. Resour. Newsl. 127, 29-34.

\section{How to cite this article:}

Kouonon, L. C., Kouadio, B. A. S., Koffi, K. G., Goba, K. A. E., Kone, M., 22020. Structuring of the ginger (Zingiber officinale Roscoe.) cultivation system in Côte d'Ivoire and assessment of the morphological variability of rhizomes. Int. J. Curr. Res. Biosci. Plant Biol. 7(6), 13-25.

doi: https://doi.org/10.20546/ijcrbp.2020.706.002 